\title{
Towards sustainable tourism in Bali
}

A Western paradigm in the face of Balinese cultural uniqueness

Sylvine Pickel-Chevalier and Budarma Ketut

\section{CpenEdition}

\section{Journals}

Electronic version

URL: http://journals.openedition.org/tourisme/1187

DOI: 10.4000/tourisme.1187

ISSN: 2492-7503

\section{Publisher}

Éditions touristiques européennes

\section{Electronic reference}

Sylvine Pickel-Chevalier and Budarma Ketut, «Towards sustainable tourism in Bali », Mondes du Tourisme [Online], Hors-série | 2016, Online since 01 September 2016, connection on 30 April 2019. URL : http://journals.openedition.org/tourisme/1187; DOI : 10.4000/tourisme.1187

This text was automatically generated on 30 April 2019.

\section{cc)}

Mondes du tourisme est mis à disposition selon les termes de la licence Creative Commons Attribution

- Pas d'Utilisation Commerciale - Pas de Modification 4.0 International. 


\title{
Towards sustainable tourism in Bali
}

A Western paradigm in the face of Balinese cultural uniqueness

\author{
Sylvine Pickel-Chevalier and Budarma Ketut
}

\section{Introduction}

1 As with many tourist destinations, Bali has accessed modernity and globalization through tourism (MIT, 2011; Liu, 2003). This is not a new phenomenon since tourism in Bali has been developing for almost a century, since the first European tourists arrived in the 1920s. At the outset of the process, artists and scientists (Walter Spies, Colin McPhee, Covarrubias, etc.) contributed to creating and diffusing the idea of Bali as a "paradise" in the Western world (Vickers, 2012). This first international tourism influx highlighted Bali's cultural and natural uniqueness, which has become a national interest since 1950 in the context of independence (Brown, 2011). The new Indonesian government supported the development of domestic tourism in Bali, as a marker of national identity which must be re-appropriated by the young nation under construction (Picard, 1992; Cabasset, 2000; Vickers, 2012). The 1970s represented a new step in tourism development, thanks to the modernization of the airport, which allowed a spectacular development of tourist numbers (Cabasset-Semedo, 2011). In 2015, the island attracted 4 million tourists coming from several Western countries (Australia, United Kingdom, USA, France, Germany, Holland, etc.), but even more so from Asian countries (China, Japan, Malaysia, South Korea, Singapore, etc.). And this number has now been overtaken by domestic visitors, estimated to be 7.15 million Indonesian tourists in 2015 (Bali Government Tourism Office, 2016.)

2 Yet tourism has been a part of the evolution of Balinese society for almost a century. The relationship between guest and host populations and the opening/closing process that it requires (Picard, 2010) has contributed to shaping today's Balinese society in its diversity. Nonetheless, tourism has also brought about significant changes in the traditional balance, especially with the dicrease of the rice fields that used to make up the structure of the social organization through the Subak system, the traditional irrigation unit 
(which has been registered on the Unesco World Heritage List since 2012). Besides, this huge influx of tourists has resulted in important impacts on the environment (Knight, Mitchell and Wall, 1997) and questions the equality of access to water, since the hotels have priority over the local people - who are deprived of tap water in the daytime from 10 a.m. to 6 p.m., in order to leave the majority of water for the hotels.

In this context, Bali has been selected as a privileged place, a laboratory for analysis: a small island visited by large numbers of tourists and where sustainable tourism projects have been tried for 40 years. Indeed, the Bali Sustainable Development Project (BSDP) was conceived very early in 1987 and was initiated in 1989 as a five-year development scheme to encourage vigorous economic development in Bali, while also ensuring and enhancing traditional cultural values and protecting the integrity of the natural environment. By November 1992, a Sustainable Development Strategy for Bali had been submitted to the provincial government, and during 1993 the Government of Bali had begun to incorporate many of its recommendations when preparing the five-year development plan for 1994 to 1999 (Mitchell, 1994). The projects provided numerous opportunities for study in the 1990s (Gertler and Martopo, 1991; Hyma and Kindon, 1992; Yaman, 1991; Wall, 1992, 1993; Mitchell, 1994). This interest seems to have decreased in the twenty-first century, whereas the problem of pollution and lack of environmental management seems to still be on the increase.

4 This situation means it is necessary to ensure that a global paradigm - sustainable development - is suitable for a local society that has developed a very different concept of social and natural environment. Can the universal proposal of "sustainability" associating economy, society and environment, but fundamentally based on a Western concept of nature - defined by its externality with humanity (Pickel-Chevalier, 2014) - and society based on an ideal of individualism and equality - be appropriated by the Balinese cosmological philosophy called Tri Hita Karana? If both proclaim a desire to create a balance between mankind and nature, do they have the same meaning? How do the Balinese integrate nature into their daily lives, which are deeply structured around their religion and culture? Can "sustainability", which pretends to be "universal", but is based on a Western paradigm, be incorporated into a world which is not homogeneous? In order to answer this, we will first go back to the historical relationship between Bali and sustainable development issues, which date from 1987. Then we will study in more detail the specificities of the Balinese relationship with the environment through the HinduBalinese philosophy called Agama Hindu Dharma and the local paradigm of Tri Hita Karana. Finally, we will question the possible suitability of international and local conceptions of "sustainability", which are sociocultural constructions, and the possible emergence of innovative new models by syncretism. Even though sustainable development involves three components - the "trinity" (Farrell, 1999) of economy, society and environment - in this article we focus only on the latter aspect, which is the integration of environmental issues within Balinese society. The social effects, which are also very complex, will be studied in other articles.

\section{Methodology of research}

Our methodology is based on cross analysis of international literature reviews, observations and detailed interpretative interviews. It consists of: 
1/ An analysis of international literature reviews and statistical studies on the official integration of sustainable concepts in Bali, dating from 1987.

2/ The comparison of a sustainable tourism paradigm - based on the Western dichotomy of humanity and nature (which emerged in medieval Christian discourse) and individualism (which emerged in the Renaissance and sixteenth-century humanism) and the Tri Hita Karana cosmological philosophy, through literature reviews.

3/ The active and passive observation of the Balinese people's relationship with nature and environmental management in their daily lives, which are structured through culture and religion. These observations were undertaken in several places:

- in domestic and international tourist areas, which are also recreational places for the local population, and more precisely (Illustration 1):

- Kuta Beach: South-west coast of Bali. This is the most famous beach for international tourism and in particular Australian tourists, but also visited by domestic tourists and the local population;

- Jimbaran Bay: South-west coast of Bali. The site is frequently visited by international and domestic tourists, but also the local population, especially at sunset;

- Dreamland Beach: South-west coast of Bali. This beach is most of all visited by domestic tourists and the local population. It is less popular with international tourists, especially those from Western countries;

- Uluwatu Temple: Close to Dreamland Beach. This site is highly popular with domestic and international tourists, especially during the Kecak Dance Festival. It is also a religious site for the local population.

- Nusa Dua Beach: South-east coast of Bali. Nusa Dua is most of all frequented by international tourists, especially from Western countries;

- Benoa Beach: South-east coast of Bali. The site is frequently visited by domestic tourists and the local population, but also in smaller numbers by international tourists.

- Lovina Beach: Northern coast of Bali. Visited by domestic tourists and the local population. In smaller numbers it is also visited by international tourists.

- Air Panas Banjar: Close to Lovina; northern Bali. The site is characterized by natural sulphur springs, organized into pools. The site is highly popular with domestic tourists and the local population for leisure. It is also visited by international tourists.

- at religious sites, during annual and daily ceremonies, and in particular:

- Tanah Lot Temple: South-west Bali, during the Odalan ceremony, to commemorate the creation of the temple, every 210 days;

- Ulun Danau Bretan Temple and Bretan Lake: mountainous northern Bali. Observation during daily ceremony;

- Sakenan Temple: On Turtle Island in south-west Bali during the Kuningan ceremony and the lining up of Penjors in the streets to commemorate the return of spirits to Heaven (on Turtle Island, close to Sakenan);

- Goa Gaja (Elephant Cave): Central Bali, during the Full Moon ceremony;

- Tampak Siring Temple (holy water natural spring): Central eastern Bali, during the Full Moon ceremony.

4/ Sixteen in-depth interpretative interviews with local people involved in tourism, between March 2010 and April 2013. We interviewed in particular:

- Three owners of local restaurants (in Lovina, Jimbaran and Beratan Lake);

- The daughter-in-law of the village chief living in Baturiti, who earns a living through tourism in the area;

- Two professional masseurs working on the beach (in Lovina); 
- Two tourist boat owners and guides (at Beratan Lake and on Lovina beach);

- Two owners of local hotels or villas (Denpasar and Lovina);

- One coffee producer and retailer at Amertha Yoga Agrotourism, near Ubud;

- Two wardens at natural tourist sites (in Susunan Wadona Temple and Air Panas Banjar);

- The curator of the Turtle Island Conservation Programme (Serangan Island);

- Mr Arry Wibowo, CSR manager of the Banyan Tree Hotel (Ungasan, Jimbaran);

- Mrs Sri Utamiati, public relations and marketing manager of the Westin Hotel (Nusa Dua).

These people come from different social classes, from the highest (village chief) to the lowest (professional masseurs on the beach). In total, there are 5 women and 11 men. These observations and interviews were undertaken from 2010 to 2013 at different times of the year, in Bali, and represent approximately 70 hours of observation and 16 hours of interviews.

\section{Illustration 1. Main tourist sites in Bali}

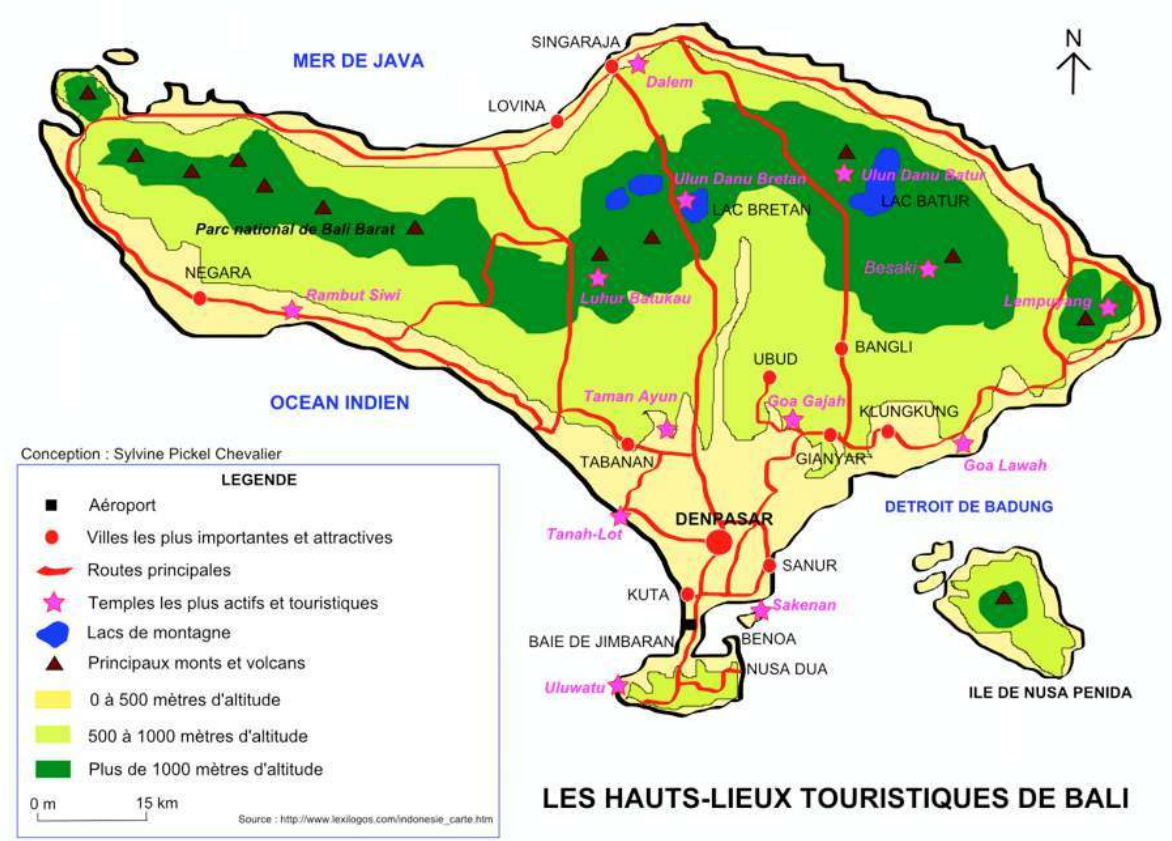

Quoted from Pickel-Chevalier and Violier, forthcoming

\section{An island concerned early on by sustainable tourism development}

Bali benefited from an early interest in sustainability, since local and national stakeholders invested, along with support from international bodies, in the Bali Sustainable Development Project (BSDP) as early as 1987, the year when the sustainable development paradigm was created (Brundtland, 1987), and even before the Earth Summit was held in Rio de Janeiro (1992). This programme was initiated in 1989 as a fiveyear development scheme to encourage vigorous economic development in Bali while also ensuring and enhancing traditional cultural values and protecting the integrity of the natural environment (Gede Putu Wardana, 2003). This early interest was provoked by a growth in the number of international and domestic tourists in Bali, with the expansion 
of the Ngurah Rai Bali Airport in 1969 and the opening of a new international resort in Nusa Dua, with the involvement of the World Bank and an international consultancy (SCETO of France) in 1971. The number of international tourists increased from 11,278 in 1969 to 436,358 in 1989 and reached 1 million in 1994, and 4 million in 2015 (Bali Bali Government Tourism Office, 2016). The tourists come from Australia, Europe and North America, but also, since the end of the twentieth century, from Asia (China, Japan, Malaysia, South Korea, Singapore, etc.). Indeed, Asia has recently become the primary geographical area providing tourists for Bali. The number of domestic tourists is even higher, increasing from 2,038,186 in 2004 to 7.15 million in 2015 (Bali Government Tourism Office, 2016).

These huge tourist flows have resulted in important impacts on Balinese society, bringing income to the local population. Tourism is now the island's number one economic resource, meaning traditional villages have become tourist-orientated, with the development of services, hotels, restaurants, performances and handicrafts (Hitchcock and Darma Putra, 2007; Cabasset-Semedo, 2011). It has brought opportunities to increase the standards of living, but also deep changes in the Balinese economic, social and natural environment. It is estimated that around 10 square kilometres of irrigated rice fields have been lost to tourist development every year since the 1980s. In addition, golf courses and hotels require large quantities of water, since five-star hotels use an average of 500 litres of water per room, per day, and non-star accommodation requires 400 litres.

Bali has interested the Indonesian government since independence, and the government has promoted the island as a cultural window on the country (Picard, 1992). As a consequence, the local and national governments have become increasingly sensitive to the negative effects of tourism and supported the new-born concept of sustainability as early as 1987 . They participated in the creation of the BSDP, with the cooperation of the Canadian International Development Agency (CIDA). The BSDP, developed with Western partnerships, included the sustainability paradigm, defined by the World Commission on Environment and Development as a capacity to maintain ecological integrity and diversity; to meet basic human needs without compromising the ability of future generations to meet their own needs; to increase inter- and intra-generational equity (or reduce injustice); and to develop community involvement (WCED, 1987). Unsurprisingly, the initial Western researchers and stakeholders involved focused much of their interest on the ecological aspects, pointing out the necessity to preserve, improve and correct damage to the natural environment, but also reduce pollution and waste through the application of clean technology and waste recycling and the management of resources, especially water, to avoid degradation of quality and access (Wall, 1993; Knight, Mitchell and Wall, 1997).

Nonetheless, the local government and population understood, despite these reports and analyses, that sustainability is a balance between the dynamic of tourism and the preservation of their culture (Hitchcock and Darma Putra, 2007; Gusti Ayu Made Suartika, 2015). The Balinese researcher Gede Putu Wardana declared in 2003: "Culture is one critical factor determining sustainable tourism development in Bali, since tourism development has been declared to be cultural tourism. Any tourism policy in Bali, therefore, must be undertaken within the cultural framework" (2003, p. 3). Indeed, the deep historical relationship between the tourism economy and the living culture of Bali produces many questions regarding management of "opening" and "closing" processes, 
to keep a balance between traditional life and modernity, within Balinese society (Picard, 2010).

11 The apparent lack of interest of the local stakeholders in the environmental stakes seems, according to all our interviews, to stem from the fact that the Balinese population considers itself to already live in "harmony" with nature, through the Tri Hita Karana philosophy that leads their daily lives and social organization.

\section{The integration of nature within Balinese society: The Tri Hita Karana philosophy}

12 It is impossible to analyze the relationship between the Balinese population and the natural environment without studying the philosophy that determines their social, cultural and religious activities. Balinese society has developed a very different conception of the universe to Christians, which had divided the world into spirituality and nature. Mankind, purported to originate from divine essence, is fundamentally separated from the materiality of the environment, intended for perdition through the "Great Division" (Larrère and Larrère, 1997) paradigm created by St Augustine in the fourth century, but applied more especially since the Renaissance in the fifteenth century (Berque, 1995; Roger, 1997). Even though this separation has been reconsidered within the concept of the ecosystem - with all living inhabitants belonging to the same system since the nineteenth and more especially twentieth century (Deléage, 1993; Larrère and Larrère, 1997), this remains rather confusing for the collective consciousness in Europe, where most of the population tend to identify nature through externality, as places where human beings are not, or are less, visible (Pickel-Chevalier, 2014).

The Balinese philosophy is on the contrary based on a cosmological philosophy that deeply connected all its inhabitants, through their own culture, in a perspective which is closer to the Greek perception of the universe: "And wise men tell us, Callicles, that heaven and earth and gods and men are held together by communion and friendship, by orderliness, temperance, and justice; and that is the reason, my friend, why they call the whole of this world by the name of order, not of disorder or dissoluteness" (Plato, Gorgias, 508a). The Balinese share this global conception of an ordered cosmos, but within a complex approach, which is a syncretic form of Shivaic Hinduism, Buddhism and animism, and can be identified at three levels. First, this Hindu-Balinese philosophy, called Agama Hindu Dharma, divides the universe into the "physical world" - sekala - and metaphysical world - niskala - (Eiseman, 1990) recalling the Socratic perception dividing the world between its "soul", or metaphysic "Idea", and its materiality (Larrère and Larrère, 1997, p. 38). At the second level, the Balinese philosophy divides the universe into two. This second division, called dwi buana, or the "two worlds concept", combines, according to Hindu philosophy, the earth called Bhuana Agung, or macrocosm, and human beings called Bhuana Alit, or microcosm. Both are created by God, who is the spirit of the two worlds. This means that no part of the two worlds is absent from the presence of divine power (Wiana I Ketut, 2007, p. 30).

At a third level, the Balinese also perceive that they deal, in any place where they live, with three spaces called Tri Mandala:

- the first place is called the utama mandala space, where temples and sacred places are located; 
- the second space is madya mandala, or the "medium place", that is to say where daily life is conducted (houses, markets, offices, public institutions or areas etc.);

- the third is nista mandala, comprising agricultural land, forests, parks, rice fields, and even back and front yards (Gede Putu Wardana, 2003).

called Tri Hita Karana: the three sources for "harmony" in life or the three causes of happiness, namely a "harmonious relationship with God, with other human beings and with the environment" (Made Adi Wirawan, 2011, p. 3). According to this philosophy, the Balinese population cannot separate humanity from spirituality and environment. At each site there must be a representation of the three spheres: the religious, human and natural - including agricultural areas. Nature is therefore deeply integrated into all the activities of the Balinese people, who are supposed to show the natural world respect, as everything in Bali is claimed to have a spirit and elements of purifying power. This means that the people cannot create a conscious gap between themselves and the environment, in a process similar to what happened in Western civilization during the Renaissance (Berque, 1995; Collot, 1997; Pickel-Chevalier, 2014).

This spiritual interpretation of the world codifies even the topography of Bali. As the Mexican anthropologist Miguel Covarrubias observed in 1937, at the very beginning of tourism development in Bali: "To the Balinese everything that is high is good and powerful, so it is natural that the sea, lower than the lowest point of the land, with the sharks and barracuda that infest the waters, and the deadly sea-snakes and poisonous fishes that live among the treacherous coral reefs, should be considered as 'tenger', magically dangerous, the home of the evil spirits" (Covarrubias, 2006, pp. 7-8). Thus, the mountains and their lakes and rivers are considered as the home of gods and the source of the land's fertility, and they stand for everything considered as holy and healthy. The middle world is the home of humans, and the depths and low places, including the ocean, are for the spirits of the underworld. The Balinese believe that the coastline is under the devilish influence of Jero Gede Mecaling, the terrible giant. Observing all these facts, Covarrubias concluded that the Balinese "are one of the rare island peoples in the world who turn their eyes not outward to the waters, but upward to the mountain tops" (Covarrubias, 2006, p. 8). Nonetheless, this fear of the ocean also means a respect for supernatural spirits. Since both constructive and destructive forces coexist constantly in the Hindu-Balinese religion (Eiseman, 1990), the Balinese believe that the sea have a purifying power. They often use it for ceremonies: for example, sea water can be used for purification before certain rituals. Besides, some important ceremonies finish by the launching of offerings into the ocean.

This global perception of nature still exists, despite the transformation generated by the recreational and tourist activities on the beach (Pickel-Chevalier and Parantika, 2015). Indeed, the Balinese population associate their modern life with their traditional spiritual activities, punctuated by daily (at least three) and annual (more than 40 ) rituals. Yet these ceremonies constantly include elements of nature, not for their materiality but for their spiritual signification. They may be symbols of fertility and wealth offered to gods fruits, flowers, rice - but also signs of purification in ceremonies: a flower in the hair; holy water given by the priest to drink in cupped hands and poured on the top of the 
head; rice stuck on the forehead with holy water (Illustration 2). Large old trees, especially banyan trees, are sacred and receive homage, such as when they are decorated. Again, components of wilderness (sea, mountain water, trees) and components of crops (rice, flowers) are not strictly dissociated in the Balinese perception.

Illustration 2. Sakenan Temple - Kuningan ceremony

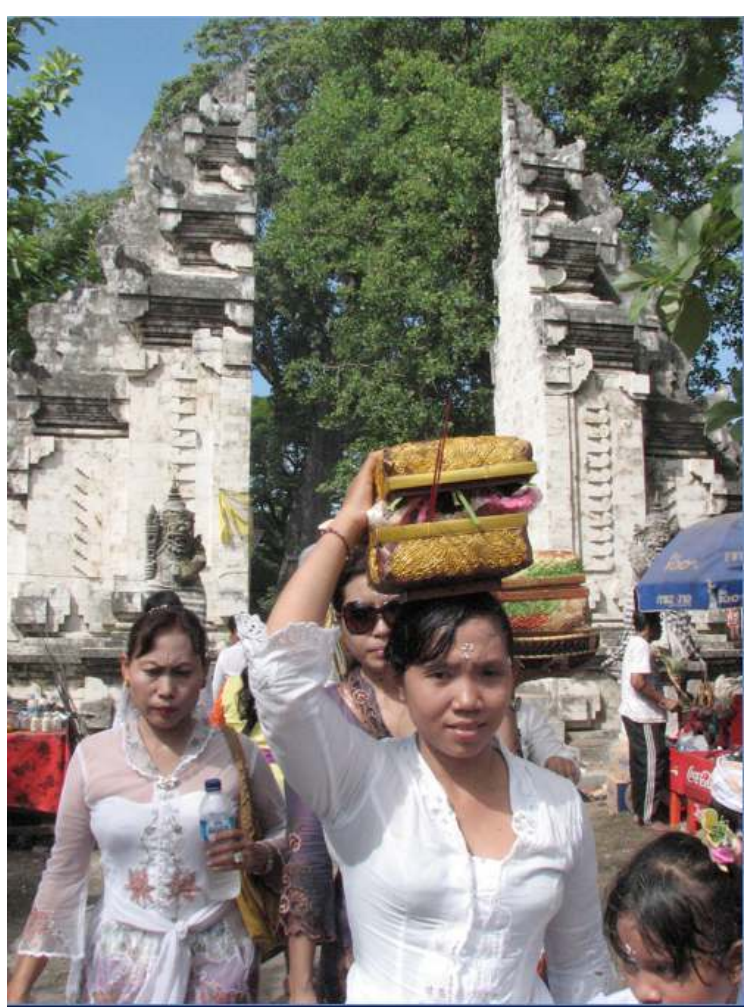

A BALINESE WOMAN CARRYING FLOWERS AND FRUIT OFFERINGS, WITH RICE STUCK TO HER FOREHEAD AS A SIgN OF PURIfICATION.

S. Pickel-Chevalier, 2013.

19 Another example is the conception of the fantastic Penjors made by each Hindu family from high bamboos decorated with flowers, to be set up in their street in front of their houses or in the temples, for the Kuningan ceremony, which commemorates the descent of gods to the world (Illustration 5). These are supposed to be a symbol of Tri Hita Karana harmony, by representing a link between nature, human handicrafts and the gods. In addition, Penjor is a token of thanksgiving for the gods who have bestowed crops on humans.

Water also has a strong spiritual meaning: seawater, but even more so water from mountain lakes, which are considered to be holy places (Eiseman, 1990), is often used in ceremonies for purification as in the Pura Tampak Siring (Illustration 3) or in the Pura Ulun Danau, at Lake Bretan, for annual ceremonies or individual processions of purification. It is important to note that, in a society where religion and culture are not ring-fenced as in Europe (Pickel-Chevalier and Ketut, 2011), the spiritual signification does not imply a strict and exclusive religious practice. Thus the hot spring at the Air Panas Banjar is not a temple. It is a recreational area, where the Balinese enjoy taking a bath and at the same time trust that they benefit from the natural capacity of the sulphur spring to purify their soul and body (interviews, 2013; Illustration 4). 
Illustration 3. Purification ritual ceremony for the Full Moon celebration, at Pura Tampak Siring

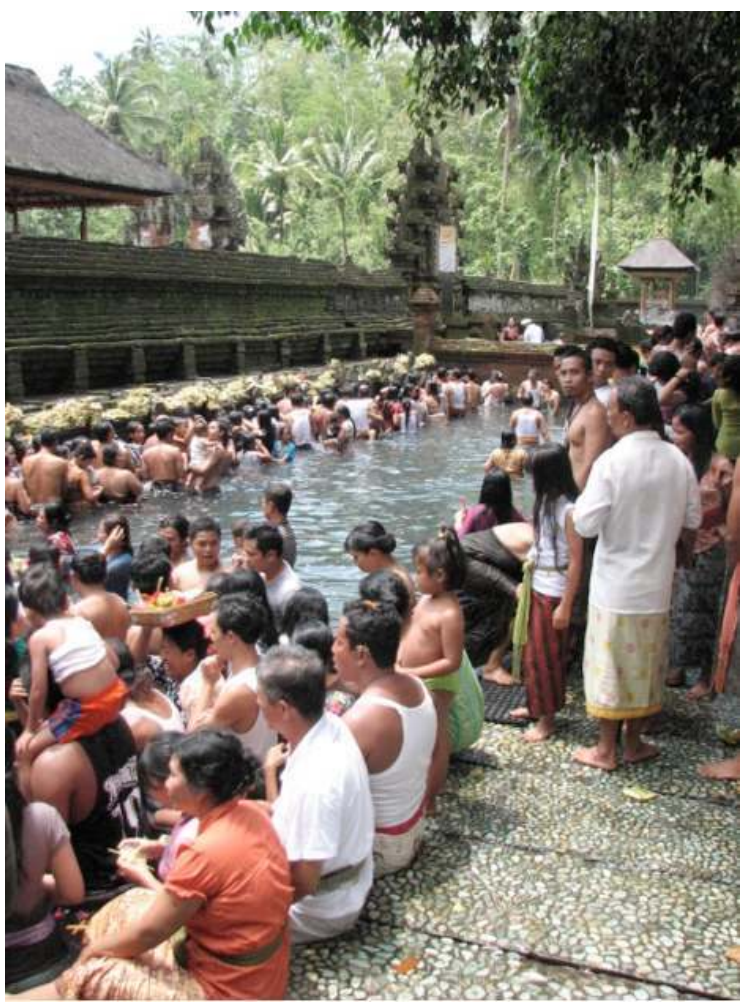

S.Pickel-Chevalier, 2012

Illustration 4. Balinese enjoying hot springs for leisure but also spiritual values in Air Panas Banjar

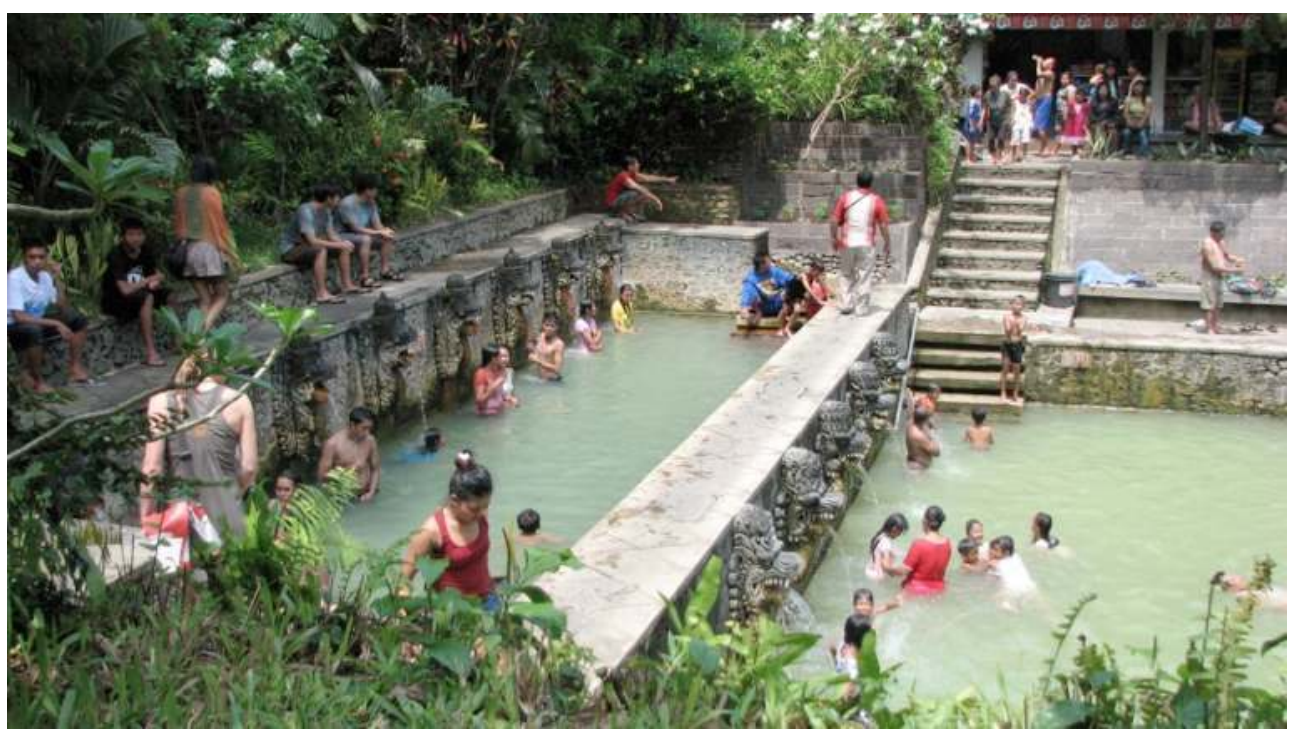

S.PICKEL-CHEVALIER, 2013.

21 Because of their holistic perception of the universe, the Balinese undoubtably have an intense relationship with nature - according to its broadest definition, combining wilderness and agriculture elements - one which is constantly associated with their daily rituals, but also activities and performances. But can this respect be aligned with the 
sustainable Western paradigm, implying conservation and preservation through environmental management?

\section{Is Tri Hita Karana sustainable? A comparison of Western and Balinese paradigms}

\section{The Tri Hita Karana concept, created for sustainability but assimilated with spirituality}

Balinese society is characterized by its strong capacity to assimilate diverse influences to build its own culture, which may come from foreigners (Vickers, 2012; Picard, 1992), in a process of integrating images of themselves conveyed by tourists, observed in other countries, such as Thailand (Evrard, 2006) or Vietnam (Michaud and Turner, 2006). Surprisingly enough, the Tri Hita Karana paradigm is also a syncretic form of local and external values. Indeed, even though this philosophy has now developed across the island, it is actually a recent concept, created in 1967 by Professor I. W. Mertha Sutedja. It is based on Hindu-Balinese religious teachings and more especially the Tri Mandala cosmology dividing the world into three spheres (the gods' home, mankind's world and nature including agriculture areas), but in a hedonistic form: "the three reasons for happiness" (Tri means three, Hita means well-being and Karana means cause). According to Dr I. W. Mertha Sutedja, "Tri Hita Karan philosophy embodies universal values and represents harmonious and balanced human relationships with the spiritual, social and natural environment to achieve spiritual and physical well-being. That is, between human to god, human to human and human to nature" (2012, p. 27).

However, the three components that need to be "balanced" are in fact inspired by, but different from, the Tri Mandala. This corresponds more to a model of evaluation divided into three elements, which are:

- Elements of Parhyangan ("Culture") comprising: 1. Existence of holy places (temples) in companies; 2. Use of symbols of the Hindu religion (statues, banners, shrines, etc.); 3. Use of ritual ceremonial implements of the Hindu religion; 4. Communication/relations with hotels; 5. Maintenance and conservation of holy places; 6 . Quality improvements to Balinese culture; 7. Application of traditional architectural concepts in Bali; 8. Arrangement and layout of holy places; 9. Religious activities performed both daily and periodically; 10. Contribution and participation from the business side in religious activities.

- Elements of Pawongan (“Community") consisting of: 1. Atmosphere of inter-employee and management relationships; 2. Existence of social organization within the company; 3. Local manpower, composition within the company; 4 . Improvement of the potential of local manpower; 5.Atmosphere within the company - community relations; 6. Community's business capability and ability for improvement; 7. Improvement of the company's human resource development; 8. Improvement of the communal human resource capabilities; 9. Sympathy for humanity's problems; 10. Business contribution to and participation in preserving Balinese cultural development.

- Elements of Palemahan ("Environment") consisting of: 1 . The company's commitment to the quality of the environment; 2. Application of styles and concepts of Balinese architecture; 3. Preservation and development of the ecosystem; 4. Management of waste materials (fluid matter, solid matter and gas); 5. The company's participation in local, national and international problems; 6.Clear-cut organizational arrangements in managing the 
environment; 7. Careful use of energy and natural resources; 8. Style of rooms, buildings, etc. in harmony with Balinese culture; 9. Environmental management according to valid/ positive laws; 10. Periodical review and evaluation of environmental management. (Mertha Sutedja, 2012, pp. 27-28)

More than a philosophy, the Tri Hita Karana is already an attempt at a concrete application of the global Hindu values in the modern world, and is especially attuned to companies and more precisely to hotels which were then growing rapidly in Bali. Nonetheless, this approach testifies to a syncretism between international centres of interest and Balinese specialties. In this context, the Palemahan closely associated "natural" elements (waste, energy) and cultural (Balinese architecture) elements in a global concept of "environment". But this new model has not been entirely assimilated by the local population. If the global theory of Tri Hita Karana has been adopted by them, they mostly ignore its requests concerning a material perception of the environment through management. Most Balinese appropriate Tri Hita Karana as a hedonist philosophy of the Tri Mandala, and continue to see and use elements of nature only for their spirituality (surveys, 2010-2013). This fact shows up in particular in ceremonies, where the components of nature are celebrated for their spiritual value, without much concern for environment management. For example, the big trees are dressed, as a sign of respect, but nobody is shocked if they are surrounded by waste, especially if they are offerings (Illustration 5). One of the problems comes from the fact that these offerings that used to be wrapped in bananas leaves are nowadays placed in plastic bags, which cause a huge impact on the environment, since they use tonnes of them each year. 


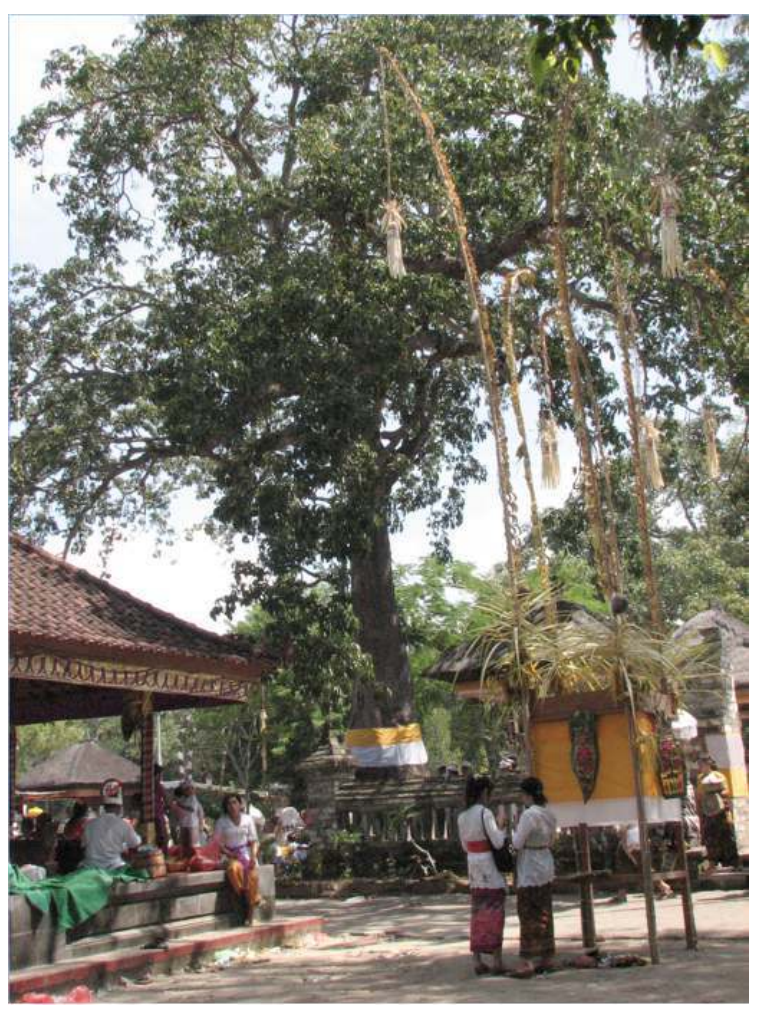

The quest for "harmony" with nature in ceremonies is shown by: dressing sacred trees, setting up Penjors made from high bamboos decorated with flowers, fruit and roots, and offerings of fruit and flowers.

Pura Susunan Wadonan, S. Pickel-Chevalier, 2013.

Although the educated population are starting to become sensitive to environmental protection (students, academics, politicians), these issues are not important for the lowest classes, who continue to throw their garbage out onto the streets. There is also a contrast between the behaviour inside one's property, which is always carefully taken care of - even in very modest houses - and outside in public areas, which do not seem to interest anybody. Actually, these public areas are supposed to be managed by the community elements - Banjar, which is the Balinese municipality - and the local government. But despite the official policy of sustainable development, created as early as 1987, and all the studies and recommendations that have followed about the necessity of a policy of ecosystem conservation, protecting landscapes, developing energy efficiency, and minimizing pollution and waste through the application of clean technology and waste recycling, official involvement is still extremely insufficient. A service of waste collection with lorries does exist but it is still well below the needs of an island of 4.225 million inhabitants (2014) and 11 million visitors per year.

\section{Towards a new innovative model: Tourism and hotels as vectors for the integration of sustainability within Balinese society}

We understand that this difficulty in integrating the policy of nature preservation comes from the fact that it is almost impossible for the Balinese to identify nature through externality. Indeed, the will for conservation implies the ability, in the collective 
consciousness, to disconnect the vital issues of the environment - food, resources, etc. from daily life. This capacity is deeply associated with urbanity. It is the result of the long-lasting historical process, in Western civilization, that has developed since the Renaissance - the invention of the "landscape" (Berque, 1995; Collot, 1997; Roger, 1997; Schama, 1999), which is a reinterpretation of nature as an external object of art that can be painted - and which triumphed during the Industrial Revolution - and the enlightenment of the wilderness in an industrial urban society, recodified through Romanticism (Pickel-Chevalier, 2014; Schama, 1999). Though the proportion of Balinese population still making a living from agriculture declined drastically to 23.5 per cent in February 2015 (Gde Bendesa and Asti Aksari, forthcoming), the Balinese have difficulty in seeing nature as an external object, especially since their cosmological religion identifies the world without division.

Nonetheless, tourism has progressively brought the Western paradigm into their philosophy, with the support of local and national authorities, who see this assimilation as a necessity to maintain the island's international attraction. This fact started with the creation of a national park, according to the Western definition: the West Bali National Park , covering an area of 190 square kilometres, with a further 580 square kilometres of protected reserves in the highlands to the east. In total, this accounts for some 10 per cent of Bali's total land area $\left(760 \mathrm{~km}^{2}\right)$, essentially composed of forested mountains, coasts and off-shore reefs, but including several ecosystems (lowland rain forests, savannah, forests along the beaches). This national park was first recognized as an area of importance in 1911, thanks to a European study led by the German biologist Dr Baron Stressman, which found rare species of endemic birds including the Bali starling. Since a lot of other rare animals live in this area (species of deer and monkey, birds, rare java buffalos, etc.), it has been protected by the King's Council by decree since 1947, as a natural park. After independence, the park became a "nature reserve" in 1978, before becoming the West Bali National Park in 1984. The management of the park is clearly for conservation, with limited access (tourists need a guide; free access is forbidden). Little accommodation exists, and only strictly on the boundaries of the park. The development of the status of this area into a national park is directly linked with the Third World National Parks Congress that was organized in Bali in October 1982. The event called for the national and local governments to get involved (since Bali was promoted as an international "window" to Indonesia by the government) and to develop a national park in Bali (Milne, 2003).

Another example of a policy of conservation, directly linked with Western sensitivity and the image that the Indonesian authorities want to spread in the context of globalization, is the new policy of management of the Balinese turtles. Due to the massive growth of sea turtle hunting in Bali from the 1960s to 1990s, which caused an international outcry, the Indonesian government passed legislation in order to protect the endangered sea turtle population (Jensen, 2009). In this context, the Turtle Island or Pulau Serangan Institution was created, on a peninsula in the south-east of Bali. This site has been designed to become the home of the Turtle Conservation and Education Centre. On a site covering 29 acres, turtle eggs are taken care of in order to be reintroduced into the wild, but also to raise turtle awareness among the local population to avoid hunting them for ritual needs. The place has also become an internationally attractive tourist site, giving a good image of Balinese conservation management, even though in reality mentalities are complicated to change, especially among members of the Balinese lower class, who continue to use them 
for ceremonies - because of the religious signification of the turtle, which is sacred - but also to sell them to foreign buyers such as Japan, Singapore and China. In order to help the local population to assimilate a new perception of the turtle as an animal that needs protection, the turtle conservation programme participates in the Balinese tradition by donating some turtles for the specific temples ceremonies which absolutely require them. The education programme also includes visits to the centre by schools in order to help young Balinese to accept the turtle as part of a living heritage of which they can be proud. The international touristic interest in these turtles contributes to this phenomena of integration, through a characteristic process of re-appropriation of their heritage by locals, enlightened by foreign tourists (Lazzarotti and Violier, 2007; Lazzarotti, 2011). Thank to those policies, illegal hunting has declined, but still exists (Jensen, 2009).

The influence of the Western perception on an environment is even more visible in tourist areas. Indeed, contrary to what is generally said, Western tourist sites, such as Nusa Dua, are less visibly polluted. This does not mean that they are not affected by widespread pollution of the earth or water, but since Western tourists are very sensitive to the visible cleanliness of environment, which symbolizes "nature" for them (PickelChevalier, 2004, 2014), their tourist sites such as Nusa Dua benefit from an active policy of cleaning, which is not publicly funded but comes from the big private resorts, often supervised by Western companies (Gede Putu Wardana, 2003). In addition, a high level of visible pollution, especially of the water, can discourage Western tourists from coming. Dreamland Beach, where the tourists reach the beach by following a small river that is sometimes very visibly polluted by rubbish, illustrates this objection. Even though the beach itself is the type of landscape which is usually appreciated by Westerners (big blue waves on white sand at the foot of the mountain), the place is frequently visited by domestic tourists and some Asian tourists, but hardly ever by Westerners (Illustration 6). 


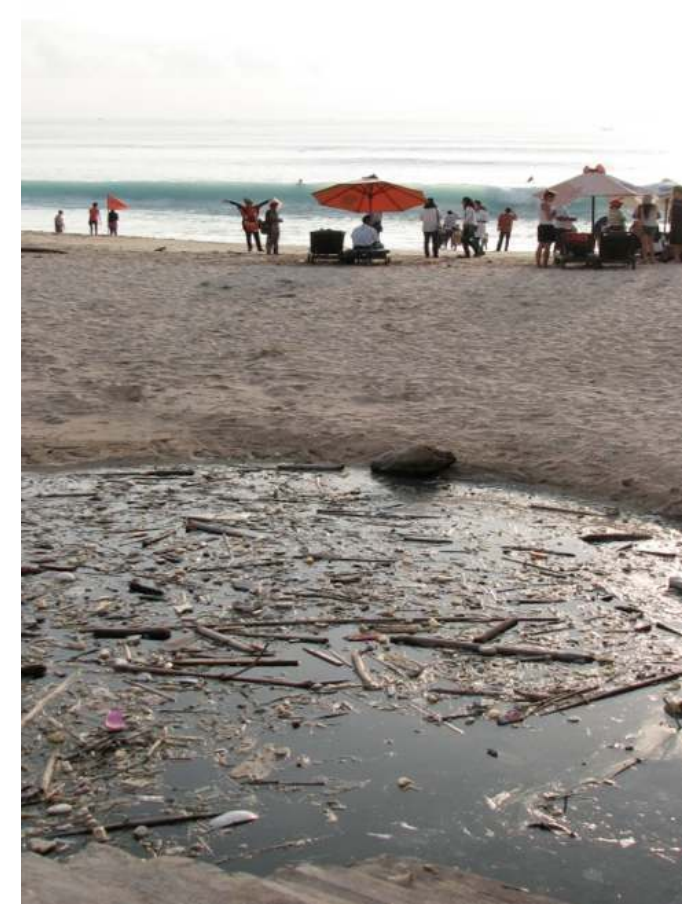

THE ENTRANCE TO DREAMLAND BEACH DESTROYS THE IMAgE OF "DREAMLAND" FOR WESTERN TOURISTS BY THE SIgHT OF STAGNANT WATER WHICH IS OFTEN HIGHLY POLLUTED. IT DOES NOT PARTICULARLY SEEM TO WORRY THE DOMESTIC TOURISTS, WHO ARE ENJOYING THE BEACH IN THE BACKgROUND.

S. Pickel-Chevalier, 2013.

Finally, the influence of international tourist activity on the assimilation of the Western concept of environment, defined through its materiality, also shows itself particularly in hotels, which represent a huge part of the economy (3,555 hotels). In fact, they are responsible for the creation of a new local label, built on a syncretism of Western and Balinese values: the Tri Hita Karana Label, created in 2000 and recognized by UNWTO in 2004 (PHRI, 2014). Their objective is on the one hand a response to the tourism "megaprojects" of the 1990s, which were contested by Balinese public opinion - such as the Garuda Wisnu Kencana on the Bukit Peninsula, the Bali Nirwana Resort at Tanah Lot, the Bali Turtle Island Development on Serangan Island, the Bali Pecatu Graha Resort, and the beach reclamation at Padanggalak, to name but the most infamous ones. As explained by M. Picard and A. Vickers (forthcoming), these projects were generally objected to on account of the damage they inflicted upon the island's environment, such as air and water pollution, beach erosion and reef destruction, water and electricity shortage, and saturation of solid waste disposal. On the other hand, they also intend to convince international tourists of the capacity of hotels to respond to Western sustainable development criteria (local incomes, social issues, energy efficiency, minimizing pollution, waste recycling, etc.), and the population of their competence to promote Balinese cultural uniqueness (the presence of temples in the hotels, organized daily ceremonies, offerings, organization of the rooms with respect to the gods, disseminating the Tri Hita Karana values to guests, etc.). This label was adopted by Indonesia's Tourism 
Law No 10 in 2009 and integrated officially as a part of the Bali province's green and clean programme by the regional government in 2010. There has been a memorandum of understanding between the institution in charge of the Tri Hita Karana Label and the Indonesian Hotel and Restaurant Association (IHRA). As a result, in 2015, 148 hotels were participating to the programme. As with sustainable development labels in France (where the resorts that invest the most in the Blue Flag scheme are the biggest ones, which suffer from a poor image due to "concrete" and large-scale construction), we can observe that it is essentially the most expensive (five- and four-star) hotels which get involved, since this label has started to become a guaranty of quality and requires large levels of investment. This fact also shows the new tendency of international hotel chains, which represent $25 \mathrm{p}$ er cent of hotels in Bali (PHRI, 2015), to adopt Green Globe certification, which became EarthCheck in 2008. If this certification is aimed at implementing the Agenda 21 principles (Harris et al., 2002), it is interesting to observe that in Bali the Tri Hita Karana Label is mostly associated with international hotel chains. The objective seems to be to benefit from international standing through the Australian label EarthCheck and to gain local approval with the Tri Hita Karana Label.

\section{Conclusion}

31 The study, which is fundamentally based on Indonesian - particularly Balinese - and French cross analysis, due to the nationality of the two researchers who led this analysis, leads us to the conclusion that it is difficult to impose the so-called universal concept of sustainability on local cultural uniqueness, as in Bali's society. In fact, even though the sustainable paradigm is based on a quest which may look like a universal interest balancing economy, society and the environment - it raises the question of the universality of the definition of those terms. If the priority depends on the level of development of the countries concerned (Turner, Pearce and Bateman, 1994; Hunter, 1997; Mowforth and Munt, 1998; Liu, 2003), it also reveals more issues around the fundamental essence of relationships between society and nature, which are not universal. The sustainable paradigm is clearly structured from a Western culture which has defined nature by its externality to humanity since medieval times, and developed a discourse of equity and individualism since the Renaissance in Europe. Balinese society has developed a holistic perception of the world, through Agama Hindu Dharma, Dwi buana and Tri Hita Karana philosophies, which define man and nature, and the deep-rooted connection between them and the gods, very differently. If "nature" is omnipresent in the daily life of the Balinese, the respect they have is more for their spiritual characters than their material reality. This means that their constant integration of elements of nature into their activities does not imply environmental management, and most of the population is still relatively insensitive to this issue. Yet, to be efficient, the concept of sustainability needs an understanding of diversity and the integration of it through flexibility (Liu, 2003; Knafou and Pickel-Chevalier, 2011; Buckley, 2012). And this is indeed what we are starting to observe through the two-pronged process of, firstly, the will of national and local authorities to cultivate the image of Bali as a window and model of Indonesia to the world, and secondly, the interests of the big hotels, especially the chains. Because nature and Balinese culture are part of their economic capital, they contribute to developing a concept built on a meeting of the Western material definition of the environment and the Balinese spiritual representation of it. Since those hotels need the 
support of the local authorities - which may have been threatened because of the scandals of the mega-projects in the 1990s - and since they have the economic capacity to invest in environmental management, they are among the first stakeholders to participate in the creation and application of this new intellectual syncretism, which can be progressively spread among the population. However, the capacity of those sustainable development labels to really decrease environmental pollution and erosion, and increase respect for Balinese traditions, will need forthcoming additional analysis. Nevertheless, Bali's society has for centuries been characterized by its deep capacity to assimilate diverse influences within its traditional activities, trying to adapt to modernity without losing its cultural uniqueness (Vickers, 2012; Hitchcock and Darma Putra, 2007; Picard, 2010). It is a fact that this association of Tri Hita Karana philosophy and sustainable sensitivity for now concerns only the intellectual elite and the managers who control the big hotel chains. Nonetheless, we might witness in the future a process of dispersion. This further analysis into the phenomena of popular integration and rejection, and their global consequences for the structure of Balinese society, will require further research in the future.

\section{BIBLIOGRAPHY}

Bali Government Tourism Office, “Statistics”, 2016, [http://www.disparda.baliprov.go.id/en/ statistics2].

I Komang Gde Bendesa and Ni Made Asti Aksari, "From an agricultural to tourism domination of the Balinese economy", in Sylvine Pickel-Chevalier and Philippe Violier (eds.), Tourism in Bali: Means of Sustainable Development?, Cambridge Scholars Publishing, forthcoming.

Augustin Berque, Les Raisons du Paysage. De la Chine antique aux environnements de synthèse, Ed. Hazan, 1995.

Colin Brown, A Short History of Indonesia: The Unlikely Nation?, Talisman, 2011.

Gro Harlem Brundtland, Report of the World Commission on Environment and Development: Our Common Future, 1987 [http://www.un-documents.net/our-common-future.pdf].

Ralf Buckley, "Sustainable tourism: Research and reality", Annals of Tourism, Vol. 39, No 2, 2012.

Catherine Cabasset, "Indonésie, le tourisme au service de l'unité nationale ? La mise en scène touristique de la nation”, PhD thesis, Paris 4 University, 2000.

Catherine Cabasset-Semedo, "L'évolution des stations touristiques : quel développement durable ? Mondialisation et aménagement touristique à Bali (Indonésie)", in Philippe Duhamel and Kadri Boualem (eds.), Tourisme et Mondialisation, "Mondes du tourisme", Espaces tourisme et loisirs, 2011.

Michel Collot (ed.), Les Enjeux du paysage, “Ousia”, Vrin, 1997.

Miguel Covarrubias, Island of Bali, Periplus Classics, 2006 [1937].

Jean-Paul Deléage, Histoire de l'écologie. Une science de l'homme et de la nature, La Découverte, 1993. 
Fred B. Eiseman Jr, Bali: Sekala \& Niskala: Essays on religion, ritual and art, Tuttle Publishing, 1990.

Olivier Evrard, L'Exotique et le Domestique. Tourisme national dans les pays du Sud : réflexions depuis la Thailande, Presses de Sciences Po, 2006.

B. H. Farrell, "Conventional or sustainable tourism? No room for choice", Tourism Management, Vol. 20, Issue 2, 1999.

Gede Putu Wardana SH. MM., Sustainable Tourism in the Balinese Perspectives, Government of Bali Province, 2003.

Leonard O. Gertler and Sugeng Martopo, "Sustainable development for Bali”, Publication Series, no 7, University Consortium on the Environment Editions, University of Michigan, 1991.

Gusti Ayu Made Suartika, "Sand, Sea and Ceremony: Conflict over the Littoral Public Realm in Sanur, Bali”, Procedia - Social and Behavioral Sciences, Vol. 179, 2015.

Rob Harris et al., Sustainable Tourism: A Global Perspective, Butterworth-Heinemann, 2002.

Michael Hitchcock and I Nyoman Darma Putra, Tourism, Development and Terrorism in Bali, Ashgate, 2007.

Colin Hunter, "Sustainable tourism as an adaptive paradigm", Annals of Tourism, Vol. 24, No 4, 1997.

Bala Hyma, and Sara Kindon, “A Review of the Bali Sustainable Development Project: Village Surveys from a Gender Perspective", Publication Series, no 29, University Consortium on the Environment, University of Michigan, 1992.

Audrey Jensen, "Shifting Focus: Redefining the Goals of Sea Turtle Consumption and Protection in Bali”, in Independent Study, Project (ISP) Collection, Paper 753, 2009 [http:// digitalcollections.sit.edu/isp_collection/753].

Rémy Knafou and Sylvine Pickel-Chevalier, "Tourisme et développement durable : de la lente émergence à une mise en œuvre problématique", in Les nouvelles dynamiques du tourisme dans le monde, 2011 [http://geoconfluences.ens-lsh.fr].

Drew Knight, Bruce Mitchell and Geoffrey Wall, "Bali: Sustainable Development, Tourism and Coastal Management”, Ambio, Vol. 26, No 2, 1997.

Catherine Larrère and Raphael Larrère, Du bon usage de la nature. Pour une philosophie de l'environnement, Alto Aubier, 1997.

Olivier Lazzarotti, Tourisme et patrimoine. Histoire, lieux, acteurs, enjeux, "Sup Tourisme”, Belin, 2011.

Olivier Lazzarotti and Philippe Violier, Tourisme et Patrimoine. Un moment du monde, Presses de l'université d'Angers, 2007.

Zhenhua Liu, "Sustainable tourism development: A critique", Journal of Sustainable Tourism, Vol. 11, No 6, 2003.

I Made Adi Wirawan. Tri Hita Karana: Kajian Teologi, Sosiologi dan Ekologi Menurut Veda (Tri Hita Karana: A study of theology, sociology and ecology), Pradnya Paramita, 2011.

I. W. Mertha Sutedja, Tri Hita Karana and world peace: Bali Hinduism philosophy of life, Pernerbit Paramita, 2012 [1967].

Jean Michaud and Sarah Turner, "Contending Visions of a Hill-Station in Vietnam", Annals of Tourism Research, Vol. 33, No 3, 2006. 
Robert C. Milne, “World Heritage and World Parks Congress: Perspectives, 1962-2003”, World Heritage at the Vth IUCN World Parks Congress, Durban (South Africa), 8-17 September 2003.

MIT, Tourisme 3 : La Révolution durable, “Mappemonde”, Belin, 2011.

Bruce Mitchell, "Sustainable development at the village level in Bali, Indonesia", Human Ecology: An Interdisciplinary Journal, Vol. 22, No 2, 1994, p. 189-211.

Martin Mowforth and Ian Munt, Tourism and Sustainability: New Tourism in the Third World, Routledge, 1998.

PHRI, “Tri Hita Karana Award 2014”, PHRI Bali, 2014 [http://www.phribali.or.id/news/3372.htm].

Michel Picard, Bali : tourisme culturel et culture touristique, L'Harmattan, 1992.

Michel Picard, “Bali: The Discourse of Cultural Tourism”, Espaces Temps, 2010 [http://

www.espacestemps.net/articles/bali-the-discourse-of-cultural-tourism/\%5D.

Michel Picard and Adrian Vickers, "Being Balinese in the face of tourism", in Sylvine PickelChevalier and Philippe Violier (eds.), Tourism in Bali: Means of Sustainable Development?, Cambridge Scholars Publishing, forthcoming.

Sylvine Pickel-Chevalier, L'Occident face à la nature. À la confluence des sciences, de la philosophie et des arts, "Idées Reçues", Le Cavalier Bleu, 2014.

Sylvine Pickel-Chevalier and Asep Parantika, "Expériences touristiques et ludiques sur les littoraux en Indonésie : des vecteurs de mutation du rapport au corps ? Étude de cas des plages de Bali, Yogyakarta, Jakarta et Manado", in Jean-Michel Decroly (ed.), Le Tourisme comme expérience. Regards interdisciplinaires sur le vécu touristique, Presses de l'université de Québec, 2015.

Sylvine Pickel-Chevalier and Budarma Ketut, "Bali, au carrefour du tourisme national et international occidental et asiatique : vers une homogénéisation des pratiques touristiques mondialisées ?", in La 3ème révolution touristique : identifier et comprendre les mobilités touristiques des populations des pays émergeants, Journées de la Commission nationale du Tourisme et des Loisirs, Bordeaux-Pessac, 27-28 June 2011.

Sylvine Pickel-Chevalier and Philippe Violier, "Bali, de la marge à la centralité touristique ?", in Nicolas Bernard (ed.), Tourisme et périphéries : la centralité des lieux en question, Presses universitaires de Rennes, forthcoming.

Plato, Gorgias, 508a [http://classics.mit.edu/Plato/gorgias.html].

Alain Roger, Court traité du paysage, Gallimard, 1997.

Simon Schama, Le paysage et la mémoire, Le Seuil, 1999.

R. Kerry Turner, David W. Pearce and Ian Bateman, Environmental Economics: An Elementary Introduction, Harvester Wheatsheaf, 1994.

Adrian Vickers, Bali: A Paradise Created, Tuttle Publishing, 2012 [1989].

Geoffrey Wall, "Bali Sustainable Development Project”, Annals of Tourism Research, Vol. 19, no 3, 1992, pp. 569-571.

Geoffrey Wall, "International Collaboration in the Search for Sustainable Tourism in Bali, Indonesia", Journal of Sustainable Tourism, Vol. 1, No 1, 1993, p. 38-47.

Geoffrey Wall, "Rethinking impacts of tourism", in Christopher Cooper and Stephen Wanhill (eds.), Tourism Development: Environmental and Community Issues, John Wiley, 1997. 
Wiana Ketut, Kearifan Lokal Dalam Mengelola Lingkungan Hidup (Local wisdom in managing environment), Udayana University, Denpasar, 2007.

World Commission on Environment and Development, Our Common Future, Oxford University Press, 1987.

Amat Ramsa Yaman, Sustainable Development for Forests and Protected Areas in Bali, UMI Editions, 1991.

\section{ABSTRACTS}

As with many tourist destinations, Bali has accessed modernity and globalization through tourism. In 2015, Bali attracted 4 million tourists coming mainly from several Western countries but even more so from Asian countries. And this number has now been overtaken by domestic visitors, estimated to be 7.15 million Indonesian tourists in 2015. In this context, Bali has been selected as a privileged place for analysis: a small island with huge frequentation where sustainable tourism projects have been tried, since 1987 and 1989. This situation questions the suitability of a global paradigm - sustainable development - for a local society which has developed specific concepts of social and natural environment. Can the universal proposal of "sustainability" associating economy, society and environment, but fundamentally based on a Western concept of nature - defined by its externality from humanity - and society - based on an ideal of individualism and equality - be appropriated by the Balinese cosmological philosophy called Tri Hita Karana? If both proclaim a desire to create a balance between mankind and "nature", do they have the same meaning? In order to answer this, we will first go back to the historical relationship between Balinese society and sustainable development issues, which date from 1987. Then we will study in more detail the specificities of the Balinese relationship with the environment through the local paradigm of Tri Hita Karana. Finally, we will question the possible suitability of international and local conceptions of "sustainability", which are sociocultural constructions, and the possible emergence of innovative new models by syncretism. Even though sustainable development involves three components - the "trinity" of economy, society and environment - in this article we focus only on the latter aspect, which is the integration of environmental issues within Balinese society.

Comme beaucoup de lieux touristiques, Bali a accédé à la modernité et à la mondialisation par sa mise en tourisme. En 2015, l'île attire 4 millions de touristes internationaux venant essentiellement des pays occidentaux, mais plus encore des pays asiatiques. Leur nombre est de plus dépassé par le tourisme domestique, qui atteint 7,15 millions en 2015. Dans ce contexte, Bali apparaît comme un laboratoire d'analyse privilégié, pour constituer une petite île très fréquentée où ont été tentés des projets de développement touristique durable depuis 1987 et 1989. Ce cas d'étude interroge la capacité d'un paradigme global - le développement durable - à s'adapter à une population locale, qui a développé des conceptions de la société et de l'environnement singularisées. La notion de «durabilité» se voulant universelle, en associant enjeux économiques, sociaux et environnementaux, mais fondamentalement basée sur des conceptions occidentales de la nature - définie par son extranéité à l'humanité - et de la société - basée sur un idéal d'individualisme et d'égalité - peut-elle être en adéquation avec la philosophie cosmologique balinaise appelée Tri Hita Karana? Si toutes deux affirment rechercher un équilibre entre l'humanité et la "nature ", ces derniers correspondent-il à une même réalité ? Afin d'y répondre, nous reviendrons, en premier lieu, sur l'historique de la mise en œuvre de projets de développement durable à Bali, depuis 1987. Nous étudierons par la suite plus particulièrement les spécificités de la relation de la société balinaise à son environnement, au 
travers du paradigme du Tri Hita Karana. Enfin, nous questionnerons la possible adéquation entre une conception internationale et une conception locale de la « durabilité », qui constituent toutes deux des constructions socio-culturelles, ainsi que la possible émergence de nouveaux modèles par syncrétisme. Si le développement durable intègre, certes, trois composantes - la «trinité » économique, sociale et environnementale - dans cet article, nous nous focaliserons uniquement sur le dernier aspect, à savoir l'intégration des enjeux environnementaux par la société balinaise.

INDEX

Mots-clés: Bali, développement touristique durable, Tri Hita Karana, adaptabilité Keywords: sustainable tourism, adaptability

\section{AUTHORS}

\section{SYLVINE PICKEL-CHEVALIER}

Associate Professor (Maître de Conférences), Geographer, ESTHUA, University of Angers, ESO UMR 6590

\section{BUDARMA KETUT}

Doctor of Geography, Secretary of Tourism Department, Industrial Liaison and Partnership, Bali State Polytechnic College, Denpasar, Bali 